\title{
महाभारत सनत्सुजातीय उपाख्यान
}

\section{डा. रामपाल शुक्ल}

महाभारत हमारा राष्ट्रीय महाकाव्य है। इसमें भरतवंशी राजाओं की अमरगाथा है। इसे ग्रन्थरत्न में धार्मिक, नैतिक और सांस्कृति जीवन पद्धित का चित्रण है। इसमें अनेक आख्यानोपाख्यान समाहित है। यह सनतृयुजातीय उपाख्यान महाभारत के उद्योगपर्व में वर्णित है। इसमें चार अध्याय है। जो धृतराष्ट्र के प्रश्नों का उत्तर सनत्सुंजात देते है।

सनत्सुजात ब्रहा के चारा मानस पुत्रों में से एक है इनका दूसरा नाम सनत्कुमार भी है। सनत=सर्वदा सुदु अर्थात् सुन्दर जन्म है वह सनत्सुजात है। भारतीय वाडयम में सनत्कुमार का उल्लेख अनेक ग्रन्थों में है। इस उपाख्यान में धृतराष्ट्र के प्रश्न बहुत ही मार्मिक है जो हमारे जीवन से युक्त है। इसमें 149 श्लोक है। प्रश्नोत्तर का क्रम इस प्रकार है।

विचित्रदीर्य के ज्येष्ठपुत्र धृतराष्ट्र जो व्यास के नियोग से पैदा हुए थे और जन्मान्ध थे।

विराटपुरी में जब महाभारत समाप्त हो गया धृतराष्ट्र शोक और मोह में मग्न थे, तब धृतराष्ट्र ने महात्मा विदुर से धर्मोपदेश करने को कहा- इस पर विदुर ने कहा महाराज। में शूद हूँ उपदेश प्रदान करने में में अपात्र हूँ। इस पर उन्हों ने कहा कि मेरे कष्ट निवारण के लिए कुछ उपाय करो। तब विदुर ने महात्मा सनत्सुजात से प्रार्थना की और सन्सुजात वहाँ आये उनका अर्ध्यादि से पूजन किया तब धृतराष्ट ने प्रश्न किया। प्रश्न हे महात्मन मैं ने सुना है, कि प्राणियों को मृत्यु से भय होता है, परंतु मृत्युनामक तत्व नहीं, और यह भी सुना है कि देवताओं ने मृत्यु के भय से अमर होने का उपाय किया तो मृत्यु है कि नहीं?

उत्तर- सनत्सुजात कहते हैं- कि दोनों पक्षों को यर्थाथरुप से जारी देशों पक्ष अधिकारी भेदसे सत्य हैकुछ लोग मोक को मृत्यु मानते है- परंतु में कहता हूँ कि प्रमादं वै मृत्युः अर्थात् प्रमाद (आलस्य ही) मृत्यु है। मोह अज्ञान का नाम है अर्थात् मोही (अज्ञानी) के लिए मृत्यु हैं निमोंह के लिए मृत्यु नहीं है। और प्रमाद को ही मृत्यु अप्रमाद को ही अमरत्व कहते है। यहां अज्ञान, मोह और प्रमाद को मृत्यु कहा है। क्योंकि इनके कारण ही मनुष्य पाप और जन्म मरण में फसता है। मृत्यु कोई रूप नहीं है तो उसकी सत्ता में (अर्थात् है) क्या प्रमाण है। वे कहते है- प्रमाद (अज्ञान) का कोई रूप नहीं है उसकी क्रिया से प्रतीति होती है और मूढ लोग मृत्यु से मिल एक यम नामक देवता के रूप की कल्पना करते है। यहां यम के द्वारा ही पुष्णकर्मियों के लिए मंगल और पापियों के लिए अमंगल विधान किया जाता है। यहां सनत्सुजात ने प्रसाद को ही मृत्युसिद्ध करके उसके समस्त कार्यों का वर्णन किया है। प्रमाद से क्रोध क्रोंध से काम की उत्पत्ति होती है।

सामान्यतः इस लोक में सामान्यजन मृत्यु को प्राप्त होकर जीवन मरण में पुनः फँस जाते हैं। और जो विषयासक्त नहीं है। वह मृत्यु को पार कर पुनः फँस जाते हैं। कामनानुसारी विषयों में आसक्त पुरुष सांसारिक भागों में ही जाते हैं। इस प्रकार उपदेश देते हुए कर्मबन्धन मोक्षका विवरण देते हुए प्रारंभ कर्म का उदय व आगे ज्ञानी और अज्ञानी का भेद बताया है। माना और मौन की विशेषता बतायी है। तथा लक्ष्मी प्राप्तिकें छ: प्रकार के उपाय बतायें- 1. सत्य 2. अकुटिलता 3. लज्जा 4. दम 5. पवित्रता 6. ब्रहाविद्या। द्वितीय अध्याय में मौन और उसके साधनों पर उपदेश दिया है। साथ ही वेदों का ज्ञाता भी हो परंतु पपाचरण करे तो उसे वेद भी नहीं वचा 
सकते। विद्धान और अंविद्धान के लिए कर्मफल की विषमता कही है। किस तपसे मोक्ष की प्राप्ति होगी। इस पर कहते हैं। निष्काम तप से मोक्ष मिलता है। आगे ब्राह्मण का लक्षण बताते है- जो सत्यात्मक ब्रह्म की ब्राह्मी स्थिति से कभी च्युत न हो वही सच्चा ब्राह्मण है इसी तरह केवल कषाय वस्त्र (गेरुवा) धारणा करने से मुनि नहीं होता है, मौन धारण पूर्वक साधक को मुनि कहत है। तृतीय अध्याय में ब्रह्मचर्यकी महिमा का वर्णन है।

चतुर्थ अध्याय में ब्रह्म के विराट रुप का वर्णन किया गया है सनतसुजात ने ब्रह्म के स्वरुप को कहा है कि वह ज्योतिर्मय है, एवं विश्वास यश रुप है। देवता इसी ब्रह्म की उपासना करते है।

येन सूर्यस्त तपति तेजसे द्धः

योगीजन इसी परमात्मका को देखते है इसी के प्रकाश से सूर्य प्रकाशित होता है धृतराष्ट प्रश्न करते है कि आत्म-साक्षात्कारियों की किस प्रकार की मुक्ति होती है। तब उन्होंने उत्तर दिया कि आज्ञानी लोग सकाभाव से संसार के चक्र में फंसते हैं परंतु मुक्ति की इच्छा वाले व्यक्ति वेदवृक्ष पर चढकर ज्ञान वेराग्य रुपी पंख से यथेष्ट मोक्ष सुख में लीन हो जाते है। आगे लपयोग के द्वारा ब्रह्मप्राप्ति का उपदेश देकर धृतराष्ट की स्थिति को जानकर कहते है कि जीवधारण करने वालों के विषय में तुम्हारा सोचना व्यर्थ है।

उन्होने अपने अनुभव को बतलाते हुए यह कहा है कि आत्मतत्व से सम्बन्ध शरीरादि का होता ही नहीं अतः आत्मतत्व अर्थात् परमात्मा से सम्बन्ध करना चाहिए।

सनतसुजातीय दर्शन की तुलना गीता के उपदेशों से की गयी है इसका वैशिष्टय यह है कि यह उपदेश प्रपंत्रों से हटाकर आत्मचिन्तन की और प्रेरित करता है तथा जीवन को पवित्र बनाने में सहायक सिद्ध है।

आत्मचिन्तन या ब्रह्म निरूपण के विषय में इसमें कहा गया है कि उस जगन्निभन्ता के संकल्प से वायु आदि पंच भौतिक रूप इस देह में प्रगट होते है। और फिर लय होते है उसी प्रकार ब्रह्माण्ड का भी अंत होता है। पंच महाभूतात्मक ब्रह्माण्ड भी उसी में विलीन होता है। क्योंकि कार्य का अपने कारण में लीन होना यह नैसर्गिक नियम है। अतः यह सिद्ध होता है कि सम्पूर्ण पंच महाभूतों का नियंत्रण किसी चेतन शक्ति पर अवलम्बित है। वही परमात्मका ब्रह्म ज्ञानियों के लिए अमृत है। उसी पर यह जगत स्थिर है। उसी की आज्ञा से सब जीवित है और अंत में सब उसी में विलीन हो जाते है। अत एवं वह ईश्वर, प्रभु या ब्रह्म के रूप में जगत में विख्यात है।

अंत में महाभारतीय युद्ध से मुख मलीन किये हुए, दुर्योधनार्दि पुत्रों की ममता में ग्रसित अनाथ धृतराष्ट को देश्य कर परम दयालु सनत्सुजात में कहा है राजन! शोक-मोह से विरत होकर उस ब्रह्म ईश्वर आदि को समझों सोचना व्यर्थ है। इस प्रकार सनत्सुजात धृतराष्ट को उपदेश देते है। इस उपाख्यान में आद्य शंकराचार्य जी का भी भाष्य उपलब्ध होता है। आचार्य नील कण्ठ जी ने तो सम्पूर्ण महाभारत पर नीलकंण्ठी टीका लिखी है। दोनों भाष्यों को समझने से ही यह उपाख्यान बोधित होता है।

प्राध्यापक, म.स.य.नि., वडोदरा 